\title{
The Construction of Feminine Psychology in Swahili Women's Nuptial Poetry-Unyago
}

\author{
Wangari Mwai ${ }^{1}$, Margaret Mwenje ${ }^{2}$ \& John Kirimi M'Raiji ${ }^{3}$ \\ ${ }^{1}$ Department of Literature, Kenyatta University, Kenya \\ ${ }^{2}$ Department of Psychology, Karatina University, Kenya \\ ${ }^{3}$ Department of African Languages \& Literature, University of Botswana, Gaborone, Botswana \\ Correspondence: Wangari Mwai, Department of Literature, Kenyatta University, Kenya. E-mail: \\ mwaiwang@gmail.com
}

Received: January 25, 2017

Accepted: February 18, $2017 \quad$ Online Published: March 20, 2017

doi:10.5539/jedp.v7n1p241

URL: http://doi.org/10.5539/jedp.v7n1p241

\begin{abstract}
This article examines the construction of feminine psychology in Swahili women nuptial poetry-unyago. Unyago poetry is composed and performed by Swahili women. Swahili is a community located along the coastal region of Kenya. This article, therefore, focuses on intersections between psychology and poetry in analyzing and describing how unyago poetry reveals the mindsets and emotions of Swahili women. Data for analysis in article is derived from research carried out among women of Swahili decent living at Kisumu using observation and in-depth interviews as data collection methods. Unyago poetry is viewed as confessions and revelations of the female self, the marriage institution and that of the marital partner. Worth noting is the fact that the women, whose ancestors originated from the coastal region of Kenya, have preserved the nuptial rituals and teachings therein across time and space. Through unyago, the women socialize their girls from children to women and is a deeply rooted practice in their philosophy, psychology, and culture of the Swahili people. Thus, this article contends that unyago is both a reflection of group and individual psychological reactions to cultural expression through poetry.
\end{abstract}

Keywords: unyago poetry, poetichology, women, confessions

\section{Introduction}

\subsection{Introduction to the Problem}

Literature, it is known, reflects society and therefore mirrors social experiences. Literature as an art is also a vehicle through which literary artists use various personae to vent their emotions.

Poetry, one of the genres of literature, best expresses deepest feelings by artists. Hence, poetry has been described by William Wordsworth as "the spontaneous overflow of powerful feelings: it takes its origin from emotion recollected in tranquility". Emotions are part and parcel of the human mind. Poetry and Psychology are two concepts found in two different fields of study. However, there is a close connection between poetry and psychology. This connection arises from the fact that the practice of literature, especially poetry, is derived from the creative artist's inner feelings, emotions and inspirations, and can be approached from a psychological perspective.

Robert Wallace (1991, p. 284) observes that, "All poets must learn ... from their own experience, how to court their muse, how to draw from the mysterious source, whatever it is, and deep within themselves". On his part, Plato quoted in Rowe (1986, p. 245) summarizes the relationship between poetry and psychology as:

“...virgin soul and stimulates it to rapt passionate expression, especially in lyric poetry, glorifying in countless mighty deeds of ancient times for the instruction of posterity. But if any man come to the gates of poetry without the madness of the Muses, persuaded that skill alone will make him a good poet, then shall he and his works of sanity with him be brought to nought by the poetry of madness, and behold, their place is nowhere to be found." 
Plato sees poetic inspiration as a sort of "mental instability", a necessary evil for creating lasting works of literature. This is what this article refers to as poetichology. When inspired, poets are viewed as finding their muse. Considered in this light, artistic creativity is viewed as a derivative from mysterious psychic motives and thus a subject for psychology. S. T. Coleridge describes poetry as "the best words in the best order". Poetry represents thoughts, imagination, and awareness, experiences expressed through meaning, sound, and rhythmic language in such a way as to evoke emotional response. On the other hand, psychology is the science of human mind, behavior, soul, consciousness, unconsciousness among others. The study of behavior, includes anything a person does which can be observed. It thus includes feelings, attitudes, thoughts and other mental processes.

Psychology also deals with unconscious thought processes. Modern psychologists consider unconscious processes as being more important than conscious ones. Psychoanalysis, the unconscious processes in literature are considered as impulses that lead the poet and all other artists to produce a poetical work or any other work of art. What psychologists refer to as the unconscious, is what poets label as the abyss, our wilderness or the wild, the muses or even the madness. Thus, through poetics, a rich repository of energy, of imagery, metaphor, paradox, inversion, contradiction, and often enough beauty, psychology is offered as a vehicle through which to reach greater realms of expression and unique unveilings.

\subsection{Importance of the Problem and Its Relevance to Scholarship}

This article revisits Swahili women's nuptial rites (Unyago) poetry. It interprets Unyago poetry as psychological expressions (Finnegan, 1987) of Swahili women's understanding of their roles and responsibilities as their culture demands. In this regard, the article looks at how poetic creations and performances experienced during the wedding rituals valorize and embrace the resources of the unconscious of the performers through Unyago as a form of confessional poetry Confessional poetry deals with personal and emotional experiences which are generally taboo. In this poetry, we witness a ruthless self-expression and a tone of utter openness. Confessional poetry reveals to its audience the psychological and mental state of its performers. This article, therefore, observes that in the African setting, rituals such as unyago, gives space to creativity and psychological release of in depth feelings that are a source of unending friendships to the Swahili womenfolk.

\subsection{Assumption of the Study}

This article is based on the assumption that unyago, the only Swahili women's nuptial rite, provides the best context through which to understand feminine psychology, the veiled personality, and experiences of Swahili-speaking women in relation to their culture and society.

In this regard, this article sought to examine how unyago poetry constructs feminine psychology among Swahili-speaking women in Kenya. Thus, this article underscores the centrality of unyago in defining, giving identity to, providing consciousness, reality and presence to Swahili women. This in turn brings out a strong psychological and philosophical justification of unyago poetry because it plays a big role in the existence of community members as it defines their sense of Being.

\section{Methodology}

The paper adopted a qualitative research design. It sought to describe the construction of feminine psychology through unyago as a natural phenomenon that occurs naturally without the intervention of an experiment or artificially contrived treatment (Seligar \& Shohamy, 1989). This is a synchronic study because it describes the phenomenon as it exists at a particular point in time. The study population entailed Swahili Women performers and participants of the unyago rite. The informants were elderly Swahili women who by nurture preside over the unyago rite. The study utilized observation and in depth interviews as data collection methods. Open-ended questions were utilized during interview sessions to allow for in depth responses which in turn gave insights into feelings, hidden motivation, intuitions, interests and decisions of the respondents (Mugenda \& Mugenda, 1999).

Data obtained was presented in Swahili orthography and a translation to the nearest gloss in English provided. The recorded data was transcribed first and thereafter translated. Field notes written during observation and interview sessions were used to supplement the recorded data. This was thereafter followed by translation of the poems from Swahili to English. Unyago poetry collected was sorted out and classified into different categories such as Kilio Kitamu (bitter-sweet cry) based on related embedded values. During the analysis and interpretation of the findings, the mental pictures, cultural values and pyscho-social experiences that unyago poetry created were examined. 


\section{Discussions of the Findings}

\subsection{The Confessions}

Unyago, women's poetry performed during the Swahili women's nuptial rites, are manifestations of revelations and confessions of its creators' lived experiences, feelings, desires, and thoughts. Mwai (2010, p. 20) observes that these lived experiences are lodged in the persona's linguistic structures which emerge during vocalization, and are realized phonically in voice. The voicing is seen as a symbolic behavior, confession or the reproduction of the inner life, affections and emotions. The environment of this voice is taken to include the para-dynamism of words and communication of intense emotions without speech. Further, Mwai (2010) attests to the fact that the setting of unyago is seen as a ritualized display of shared emotions by women. Unyago poems are performed by women in various situations and present voices from various female dramatist personae. The performance of these poems enable Swahili women to articulate and confess individual as well as collective feelings, attitudes and beliefs in their culture. They are, therefore, one of the surest ways of understanding Swahili women's world-view and behavior. Through the poems, the younger women are made aware of the life ahead of them and in the process, the positives and the awkward situations of womanhood are disclosed and unveiled to them. Sigmund Freud in psychoanalytic theory (1856-1939) argues that unpleasant and painful feelings of childhood experiences are stored in the unconscious mind and may affect the person's behavior even in adult life. Through unyago poems, women seem to follow the Freud concept of expressing feelings through poems instead of suppressing them. Thus, the performance of poems is seen as an unveiling a disclosure of enclosed and unconscious texts.

Gladding (2009) contends that unresolved issues or unfinished business can manifest itself through unexpressed feelings like rage, anger, and hatred and grief guilt. These unexpressed feelings can cause physical symptoms like headaches, stress, depression or even stomach related problems. Psychological counselors therefore encourage clients to express their feelings through talking, journaling either through factual or fictional modes such as writing poems on feelings about life experiences. Venting out feelings is therapeutic and is encouraged in psychological counseling. Therefore, the realization that unyago poetry displays shared emotions by women is a psychological aspect that can bring psychological and emotional healing especially if an individual is experiencing some anxiety.

\subsubsection{Routes for Confessions}

There are various ways in which unyago poetry reveal confessions. One such way is through the use of ambivalence. Ambivalence is a psychological state of having simultaneous conflicting reactions, beliefs, or feelings towards some subject or object. Stated another way, ambivalence is the experience of having an attitude towards someone or something that contains both positively and negatively valenced components. The term also refers to situations where "mixed feelings" of a more general sort are experienced, or where a person experiences uncertainty or indecisiveness. Thus, ambivalence and paradox are indicators to the conflicted reality of unyago practice in the minds of the Swahili women.

Ambivalence has been utilized in Kilio Kitamu (bitter-sweet cry) category of Unyago poems. On the one hand, Kilio is a cry out of suffering. It is often an expression of pain, anguish or sorrow. On the face value, the dramatis personae in this poetry, appears to be doing exactly this. On the other hand, Kitamu refers to sweetness and joy. Thus, Kilio Kitamu unyago poems expresses suffering resulting to joy and conquest. During fieldwork, it was established that the context under which Kilio Kitamu poems are performed is during the rites of wedding preliminaries. Preliminary rites include betrothal, inspection of spouse, negotiations for dowry, the dowry payment ceremony, fixing the wedding date and the consummation of marriage. In all these days, the pain of not knowing the spouse, the anxiety of having to leave childhood and join a strange household, anxieties that characterise frightening roles of wifehood and motherhood are expressed by the girl. All these are viewed as kilio which young women are undergoing preparation. They are now graduating after undergoing the various activities of the rites of transition that take time, energy and space to cultivate. For the girl, as well as the women surrounding her especially her mother and her somo (traditional instructor), the wedding is a triumphant moment. Hence, they sing:

$$
\begin{aligned}
& \text { Mwanangu bado mdogo } \\
& \text { Mwanangu bado asoma } \\
& \text { Mwanangu bado kipusa } \\
& \text { Mwanangu bado mbichi }
\end{aligned}
$$

My child is still too young

My child is still at school

My child is still beautiful

My child is still unripe 


\section{Mwanangu bado mchanga}

Tamleaje mwanangu we!
My child is still too tender.

Will you bring up my daughter!

According to the women performers, the girl being initiated into wifehood is too young and, therefore, might require a governess and not a husband. On the wedding day, women cry in pain as they sing and imagine how the encounter will be. This makes them break into song imitating the girl mournfully calling her mother to rescue her from the pain that emanates from all parts of her body. The persona calls to her mother:

\section{Mama Mwanangu Mama-mama!}

Mama Mwanangu Mama-mama!

Kiuno-chauma

Tumbo-lauma

Kichwa-chauma

Paja-lauma
Mother, my mother, mother-mother!

Mother, my mother, mother-mother!

My waist-it pains

My stomach-it pains

My head-it pains

My thigh-it pains

Due to her tender age, the young girl experiences pain on her first sexual encounter. But her mother and her somo know all too well what this means and therefore, the two recreate painful memories and experiences on behalf of the young girl. The song, further, presents the duality of womanhood in the Swahili community as that of being a member of a group of women and also as an individual within the category of women. This then demonstrates that a woman's humanness and personhood brings a sense of being similar with others within a larger community. The song makes sense of what it means to be a woman in traditional Swahili society. The verse provides a backdrop through which one may configure a representation of a womanhood that mirrors an exteriority of one outside oneself. This analysis concurs with both Weedon (1987) and Alcoff (1995) studies regarding subjectivity in individuals as being mediated by social discourse and cultural practices rather than by individual motivations, intentions or preferences.

During the period of transition, the girl goes through a lot of anxiety. According to Freud, people may turn to defense mechanisms like introjection in order to deal with anxiety. In the same vein, the girl may introject or suppress her feelings out of fear and anxiety. According to Freud, introjection is a defense mechanism which occurs when a person internalizes ideas or voices of other people. Introjection refers to turning the feelings inwardly instead of expressing them. This can cause stress and some maladjusted behaviors. Therefore, the song that the persona sings from the girl to her mother expressing her anxiety, is read as a form of therapy. It also gives her an opportunity to get psychological support from her mother as she transits to marriage life. This confession can only be unwrapped through understanding the joy which these categories of women express in the poetry. Further, the use of words used such as mbichi, mchanga, mdogo, in the song are all used to describe the girl, enhance the unveiling the retention of the girl's virginal state which is also part of the conquest.

Ambivalence, introspection and the paradox between joy and suffering is further evident in this song in that the bride consummating her marriage is not expected to sing, but the women who are awaiting the consummation do so for her. This is a sign of social support which is therapeutic. Psychologically, the other women acquire the role of cheer leaders which makes the young women feel she is not alone in this new experience. These women configure the pain through reliving their past and wherein they fantasise the pain, yet very soon they will run through the narrow streets carrying the white sheet which is their flag victory, the evidence of the virgin state. Though it is gained through pain, it excites and arouses joy and celebration.

\subsubsection{Schadenfreude}

Schadenfreude literally means "damage-joy, or satire". It describes the state of pleasure derived by someone from another person's misfortune. The term, as Mwai (2010, p. 47) observes, is a German, equivalent to Schaden $($ harm) + Freude (joy). During unyago performances, women are veiled physically through wearing the hijab (Swahili: Bui bui) and emotionally since they are not allowed to express their hurts publically, freely and openly. The women, therefore, use imagery and other figures of speech, particularly satire, sarcasm and burlesque as tools to empower them to mask their utterances and express the unspeakable. These tools give the woman a licence to attack, unmask and laugh at the main person who society expects her to hold with extreme submission if not awe-the husband. The women's descriptions of their husbands are with distaste and are at variance with husbands' outward appearance and societal expectations. 
Thus, under the veil of subservience, the women evoke pleasure at the weaknesses of their husbands during their interpersonal relations. They derive pleasure and self-satisfaction at their own success and by damaging the self-esteem of their husbands. This experience by the women can best be described through the psychology concept of Schaden-freude which means, pleasure derived from the misfortune of others.

The women-specific rites give the wives an opportunity to express their inner, enclosed selves through song. Unyago poems also give them a license to attack, unmask and laugh at issues that touch on interpersonal relationships between couples. To exemplify is this, the person who laughs at her husband's financial incapability and decries:
Mama wee mama wee
My mother, my mother
Nakwambia mama wee
I tell you my mother
Mme huyu hatuwezani.
This husband we cannot cope.

Societal expectations, including his wife's are that the man is the provider and breadwinner for his wife. But he has failed to do so. The wife unmasks this when she declares that he is a beggar which is not masculine in this society. The persona explains that the husband leaves a lot to be desired. He has nothing. All they have in their marital dwelling is borrowed. The bride lists down the borrowed items which include what they have in the marital chamber:
Kitanda-cha kuazima
Godoro-la kuazima
Shuka-zakuazima
Mto-wakuazima
The bed - it is borrowed
The mattress - it is borrowed
The sheets - they are borrowed
The pillow - it is borrowed

Through fieldwork, it was established that nuptial rites have lessons for intimate moments for the women. At such moments, when with their sexual partners, the women are prepared with poetichological skills that enable them to psychologically sing songs that assist them in actual body movements. Besides, they are also taught endearing words to utter to their husband throughout such moments. The women are also taught how to give their bodies to their husbands and not necessarily their souls. These are secrets for the women folk, never to be disclosed or unmasked to her husband. Unyago is mostly rendered and perpetuated through generations of womenfolk through esoteric and poetic language that is understood only by the initiated women.

The women have designed songs that are against the male factor in a sexual relationship. It is such songs that the women dance to as they psychologically sing them to help them in their actual body movements and faked pleasure. Men are thus manipulated, but they remain beyond open to public reproach, whether they perform well or not. During initiation, the woman is instructed to feign pleasure through specific rhythmic body movements that should heighten sexual pleasure for herself and her partner. Examples of such songs that yield pleasure and also laugh at the male factor include such as:

\section{Kisu chako hakikati}

Kisu chako hakikati

Usiniharibie nyamax2

Si sharuti nakwambia

Si lazima

Tete -te- naona waniandama

Hakikati

Usiniharibie nyama
Your knife does not cut

Your knife does not cut

Do not spoil my meat 2

It is not a must I tell

It is not compulsory

Tete-you I see you are at me

It does not cut

Do not spoil my meat

The unyago period accorded women an artistic license to verbal ridicule and satirize and laugh at irresponsible men. The persona continues to ridicule and belittle the sexual performance of her male partner and expresses her domination in the entire endeavour:

Ewe mpalianyasi $\mathrm{x} 2$

Mbona mambo yakulemea?

Hakikati, usiniharibie nyama
You brought the grass together (prepared me)

How come you cannot manage now?

It does not cut, do not spoil my meat 
Unyago provides an opportune moment for Swahili women to collectively express their inner emotions in situations that society did not provide for in ordinary daily life. Literally, women got away with harsh but veiled assessments of men or husbands during unyago performances. The songs provided a cathartic release of pent-up emotions of pain, anger and the joys that come with womanhood.

During unyago performances, it was observed that unveiling women resulted into sensual enjoyment of the inner self. The performers danced and gesticulated to express their innermost relief. They also interjected, ululated and jeered in deep understanding and appreciation of the soloists' words. They thumped their feet as they responded in the chorus with a lot of vigour and excitement. As they performed, the women convey an erotic current through their bodies. It is an ecstatic dance that sees the women loosing themselves and achieving a cathartic level of release of emotions and negative energy. The poems break the tender maternal voices and erupt into an effervescence of repressed sexual energies. By the end of each performance of this poem which was performed over and over again, there is a release of an enclosed hidden force in the women, which evokes voice more than language. In marriage therapy, this kind of preparation of the girl, for positive and negative expectations from the relationship and also from the husband is very important as the girl is helped to understand relationship and intimacy in marriage.

\subsubsection{Symbolism}

Unyago songs are riddled with two categories of symbols: verbal and physical. The physical symbols are those that cannot be reduced to vocal actions and are observable through various body movements. In this, the women reproduce their life, emotions and affections as they perform. Thus, totality of their physical performances is a reflection of internal empowerment in the performers themselves. The performance of "Kisu chako hakikati" (Your knife is too blunt) best exemplifies the use of physical symbols. In this song, the female persona expresses sexual dissatisfaction quite graphically. She sings that her partner's knife is blunt and therefore his attempts at cutting are not only useless, but also destructive to her meat. Psychoanalytically, one cannot fail to notice the heavy borrowing from domestic images. The women draw a clear analogy between a sexual encounter and their cookery.

Kisu chako hakikati

Kisu chako hakikati

Usiniharibie nyamax2

Si sharuti nakwambia

Si lazima

Tete-te-naona waniandama

Hakikati,

usiniharibie nyama.
Your knife does not cut

Your knife does not cut

Do not spoil my meat $x 2$

It is not a must I tell

It is not compulsory

Tete-you I see you are at me

It does not cut,

Do not spoil my meat.

"Usiutie mapengo msumeno wangu" (Don't break the teeth of my saw) closely relates to the song above as it also employs the use of physical symbols. However, the song borrows its symbols from carpentry. Msumeno (saw) when used on a bad and rough surface, its teeth lose their sharp ends. Thus, the saw can no longer be used effectively to cut wood. In this context msumeno is used to refer to the sharpened (kunolewa) flawless sexual performance of a woman.

The persona goes further to advise her addressee that it is not a must that he cuts her. To the persona, his attempts at cutting are scandalous making him ridiculous. To her, it devalues his maleness. The society and herself believes that he is a sexual hero. The persona suggests that instead of him trying to do something, he is incapable of doing and thus exposing his weakness, he should just refrain from sex completely.

The two songs above are good examples of the use of phallic symbol in unyago poetry. In psychoanalysis, the phallus serves as the supreme symbol of masculine power and, concurrently, of feminine lack. Phallocentrism is a term used primarily by feminist theorists to often denote the pervasive privileging of the masculine within the current system of signification. Therefore, the two songs form asexualized representation of male potency, power, and domination over their female counterparts through some object vaguely reminiscent of the penis. Common phallic symbols include sticks, staves, swords, clubs, towers, trees, missiles, and rockets. The contrast of phallus is the yonic symbol. Yonic symbols denote gynocentrism and thus femininity. In the two songs, the knife denotes a phallic symbol while meat denote a yonic symbol. Drawing from Freudian Psychoanalysis, the two 
symbols are a representation that replaces the unconscious mental content of the women as they sing. Deviation of the symbols is witnessed when the female persona requests her male partner in sex that:

\section{Mtambaji: Usiutie mapengo msumeno wangu}

Kiitikio: Aiiye
Solo: Do not break the teeth of my saw

Response: Oh yes!

In the above scenario, the saw, a phallic symbol, is designated to the female partner. The unyago is hereby interpreted as the exertion of feminine power through a cultural institution dominated by women because it accords a sense of belonging, of identity and of being a wholesome woman in Swahili society.

\section{Conclusion}

This article has attempted to analyse how unyago poetry constructs feminine psychology among Swahili women of Kenya showing how their indigenous mode of preparing them for wifehood and motherhood helps them create materials for self-fulfillment. Self-fulfillment is about self-actualization. To this end, unyago poetry has been read as representation of multiple Swahiliwomen voices in their culture and that its textual manifestation is such that it conceals conflicts and ambiguities within it. This is due to different authorial voices, hence, multiple psychological undercurrents. The varied voices within the unyago text are sub-texts operating within a contested terrain in the sense that what it appears on the surface cannot be understood without reference to the concealments and contextualization of meaning going on simultaneously to mark the text's significance. This particularly reflected in the unyago poems cited above such as "kisu chako hakikati". Unyago performances are restricted to the women's domain and within a secretive codification of meaning and, therefore, women understand its meaning but the men, and uninitiated women, do not.

This article further revealed that unyago poetry helps document feminine experiences that is a great women's poetichological tradition. Unyago is a poetry that challenges its readers with the complexity of its ambivalences, metaphors, and images, as well as startling and disrupting readers with the force of its insight, self-awareness, and psychological penetration among these women. Unyago poetry can be summarized as "a means for the psychological release of otherwise repressed enmities and tensions through a socially permissible form" (Finnegan, 1987, p. 284).

\section{References}

Alcoff, L. (1995). Cultural Feminism versus Post-structuralism: The Identity Crisis in Feminist Theory. In N. Tuana, \& R. Tong (Eds.), Feminism and Philosophy: Essential Readings in Theory, Reinterpretation, and Application (pp. 434-456). Westview Press, Boulder, CO.

Anyona, O. (1995). Oral Literature for Development (OLD)'s Strategy for Change. In L. Levert, \& M. Opiyo (Eds.), Drama and Theatre Communication in Development: Experiencesin Western Kenya. Nairobi: Kenya Drama/Theatre and Education Association (KDEA).

Banham, M., Gibbs, J., \& Osofisan, F. (Eds.). (1999). African Theatre in Development. Oxford: James Currey Ltd.

Finnegan, R. (1987). Oral Literature in Africa. Nairobi: Oxford University Press.

Finnegan, R. (1992). Oral Traditions and the Verbal Arts. New York: Routledge. https://doi.org/10.4324/9780203397237

Fisher, H. (2004). Why We Love: The Nature And Chemistry Of Romantic Love. NY: Henry Holt.

Fredrickson, B. L., \& Roberts, T. A. (1997). Towards understanding women's lived experiences and mental health risks. Psychology of Women Quarterly, 21(2), 173-206. https://doi.org/10.1111/j.1471-6402.1997.tb00108.x

Gladding, S. (2009). Counseling: A Comprehensive Profession. Pearson Education, Upper Saddle River, NJ.

Kerr, D. (1995). African Popular Theatre: From the Pre-Colonial Times to the Present. Nairobi: EAEP.

Kiima, D. M. et al. (2004). Kenya mental health country profile. International Review of Psychiatry, 16(1), 48-53. https://doi.org/10.1080/09540260310001635096

M'Raiji, J. K. (2015). The transformation of Swahili unyago and female genital mutilation into an alternative rite of passage: A poststructuralist approach (Unpublished $\mathrm{PhD}$ thesis). University of Botswana. 
Mumma, O. (1995). A Theatrical Development Model. In L. Levert, \& M. Opiyo (Eds.), Drama and Theatre Communication in Development: Experiences in Western Kenya. Nairobi: Kenya Drama/Theatre and Education Association (KDEA).

Mwai, W. (1994). Performance; An Integral part in the Teaching of Oral Literature. In Teaching of Oral Literature. A Kenya Oral Literature Association (KOLA) publication.

Mwai, W. (2000). New Wine in Old Skins; Ora-Media for Development Messages. Institute of Research and Postgraduate Studies Seminars, Maseno University College.

Mwai, W. (2010). Songs for the Bride: A Literary Analysis of Unyago Nuptial Oral Poetry. Lambert Academic Publishers.

Plato. (1986). Phaedrus (C. J. Rowe, Trans.). Wiltshire, Eng.: Aris \& Phillips.

Robertson, C. (1996). Grassroots in Kenya: Women, genital mutilation, and collective action. The University of Chicago Press.

Wallace, R. ( 1991). Writing Poems. New York: Harper.

Weedon, C. (1999). Feminism, Theory and the Politics of Difference. Oxford: Basil Blackwell Ltd. Blackwell.

\section{Copyrights}

Copyright for this article is retained by the author(s), with first publication rights granted to the journal.

This is an open-access article distributed under the terms and conditions of the Creative Commons Attribution license (http://creativecommons.org/licenses/by/4.0/). 